it is very refreshing after the sensationalism provided by much of the mass media.

There seems to be a rule that texts of this sort should encompass every new aspect of biomedicine, whether they fit easily together or not. The trouble is that discussing all these different problems often interferes with the progression of a book. For me, Leach is at his best in dealing with the dilemmas created by modern medicine, the chapters on transplants, life on the machine, and birth defects raising many poignant and relevant issues. I found the chapters on population and brains loss interesting; the former perhaps because of previous over-exposure of the topic. Brain and bchaviour control seemed not to fit the rest of the book, made me lose earlier thrcads, and could well have been omitted. Intriguing and sobering facts are raised in the discussion on the economics of life-saving; for example, the cost effectivcness of kidney transplants in averting death is far lower than the use of hospital kidney machines for this purpose. Obviously estimates of cost are approximate and liable to change, but when economics support the adoption of new techniques, the alliance is powerful. Unfortunately, there are too many factors which aro beyond costing, for oxample, in attempts to cure kidney disease: the supply of kidneys on the one hand, versus the choice of patient, machine failure, infection and good veins for cannulating on the other. Faced with these imponderables, economics seems a simple affair.

What I missed most in the book was an overall set of conclusions, suggestions or assumptions to make social judgments and to guide me out of tho mass of detail. After a catalogue of fact such as summary was needed. Who can balance and judge such difficult problems suitably? What pressures will arise with an ageing population full of degenerative disease, outdated attitudes, and with senior posts well guarded? Religious opinion is seldom quoted. 'The Christian ethic comes out clearest where it is most conservative; for example, preserving all newborns irrespective of any deformity, and the Catholic attitude to contraception. Leach feels that the old ethics provide no guidelines for many newer issues, and in a way proves this statement later in the book, for the authorities widely quoted are doctors, scientists, sociologists. Wc could be witnessing, and might urgently need, the rapid emergence of now criteria of ethical and sociological judgments. Many of these problems will not be solved by leaving decisions, for example, to "switch off" or restrict the use of machines to individual doctors and administrators.

Inevitably, some judgments are bound to be dominated more by emotion than reason, such as the discussions about "cloning" children. Leach objects to cloning largely because of the psychological problems of offspring in relation to the nuclear donor. Buti it; could be squally well asserted that these children would be highly intelligent, adaptable, woll looked after, highly adjusted to a technical age and thoroughly happy. The case nceds stating for both sides with some discussion included about basie human rights.

Finally, the title of the book. Only in the introduction are wo provided with some definition of biocrats-and epart from technical oxpertise Leach believes that they apparently have few qualifications for social judgments. After this, the "biocrats" turn into scientists and doctors, struggling to help sick, unfortunato pationts, and trying to contond with difficult medical and scientific problems, fatuous over-publicity, outdated ethics and dogma, and groups of people complaining that scientists and doctors fail to communicate with the wider public. Yet it is often they who do raise and discuss these issues rationally. In this book, Leach provides excellent reporting, but does ho make any contribution to the ethical issues that has not proviously been raised by biomedical men?

This is a good book-provocative, detailed, balanced. At last someone is getting the facts into perspoctivo.

R. G. EDWARDS

\section{RED CELL MEMBRANES}

Red Cell Membrane

Structure and Function. Edited by G. A. Jamieson and Tibor J. Greenwalt. (The American National Red Cross Scientific Symposium, Washington, DC, May 1969.) Pp. 384. (Lippineott: Philadelphia and Toronto, December 1969.) $\$ 16.50$.

THIs publication includes the papers presented at the symposium and the discussions (30 pages). It has sections on membrane structure, chemistry, membrane transport and membrane effects in red cell physiology.

Coverage of morphological aspects of structure is limited to a chapter on an ion etching technique which produces fascinating surface contours (of unknown significance) as seen by scanning electron microscopy and an extensive discussion of tho techniques and interpretation of freezcetching (or freeze-cleaving).

The section on the chemistry of erythrocyto membrancs is dominatod by considerations of protein and glycoprotein components and of glycolipids. A surprisingly large number of protein fractions havo been separated by a variety of mothods and distinguished according to various physical and chemical criteria and a few of these have now been shown to possess individual enzymatic and immunological characteristics. Substantial progress has also been mado in identifying the immunologically important cligosaccharides of the glycoprotein and glycolipid components, but there is as yet no information on the tertiary structure of these membrane components.

Treatment of the more functional aspects of erythrocyte membranes includes a very clear history of the progress of experiment and theory of monosaccharide transport and an account of recent work on $\mathrm{Na}^{+}$and $\mathrm{K}^{+}$transport in HK and LK sheep red cells. There is also an interesting discussion of the effects of experimental and pathological variations in lipid content of the membranes on some of the properties of erythrocytes.

No new picture of the erythrocyte mombrane emerges from these discussions, but the publication gives an up to date prcgress report on a variety of studies which will be of interest to those who have a particular interest in the erythrocyte. J. B. FINEAN

\section{INSECT TREATISE}

\section{Handbuch der Zoologie}

Eine Naturgeschichte des Tierreichs. Gegrundet von Willy Kukenthal. Zweiter Auflage, herausgegeben von J. G. Helmcke, D. Stark und $H$. Wermuth. Band IV. Heft 2. Hälfte: Insecta. Hauptredaktor M. Beier. Lieferungen 1 to 12. (Gruyter: Berlin, 1968-1970.)

THE original Kukenthal-Krumbach Handbuch der Zoologie, uncompleted as it was, stood as a major achievernont of German scientific scholarship. The destruction of the entire stock and blocks of this work during the bombing of Leipzig was one of the scientific tragedies of the Second World War. The Insecta part, which was completed in the original edition, is now being rewritten, and so far twelve "Lieferungen" of it are to hand, as many different, authors having participated in writing them, tho biggest single contributor being Professor Beier. Four of these parts relate to general entomology and the rest to particular groups, those so far treated all belonging to tho Apterygota and Hemimetabola. Each part (and a Lieferung may contain several parts) is separately paginated, which will be inconvenient if and when the Lieferungen come to be bound into completed volumes. The parts at hand total more than 700 large pages, and when completed the Insecta part is likely to form several large volumes, and to challenge comparison particularly with the French Traité de Zoologie. Both works, in spite of tho Furopean Common Market, have a distinetly nationalist aura. 